\title{
Pengaruh Beda Temperatur Proses Injeksi Terhadap Sifat Mekanis Bahan Polypropylene (PP) Daur Ulang
}

(Effect of Different Temperature in the Injection Process on the Mechanical Properties of Recycled Polypropylene (PP) Materials)

\author{
Jamirul Hakim $^{\mathrm{a}}$, Johanes Wawan Joharwan ${ }^{\mathrm{b}}$, Martinus Heru Palmiyanto ${ }^{\mathrm{b}}$ \\ anniversitas Muhammadiyah Yogyakarta \\ Jalan Brawijaya, Tamantirto, Bantul, Indonesia \\ 0274) 387656 \\ e-mail: jamirulhakim28@gmail.com
}

\author{
${ }^{b}$ Program Studi Teknik Mesin, Sekolah Tinggi Teknologi Warga Surakarta \\ Jalan Raya Solo-Baki KM. 2, Kwarasan, Solo Baru, Sukoharjo, Jawa Tengah, Indonesia \\ Telp. (0271) 621176, 621178 / Fax. (0271) 621178 \\ Corresponding author, e-mail: joharwan.jw@gmail.com
}

\begin{abstract}
Abstrak
Tujuan penelitian ini untuk melihat bagaimana perbedaan temperatur injeksi mempengaruhi sifat mekanik dan fraktografi bahan polypropylene daur ulang. Penelitian ini dilakukan dengan membuat spesimen multipurpose yang sama dengan ISO 294-1:2012 dengan material polypropylene daur ulang 2 kali dan proses fabrikasi mesin injection molding dengan kapasitas pencekaman 70 ton dengan material polypropylene daur ulang 2 kali. Pengujian dilakukan menggunakan uji tarik dengan ISO 527-1 dan uji impak dengan metode Charpy ISO 179. Uji impak patahan dianalisis dengan mikroskop optik digital untuk mengetahui fraktografi patahan spesimen. Hasil pengamatan mikroskop optik digital menunjukkan bahwa fraktografi pada spesimen PP daur ulang variasi temperatur injeksi $190^{\circ} \mathrm{C}, 220^{\circ} \mathrm{C}$, dan $250^{\circ} \mathrm{C}$ tidak terlalu berbeda ada rongga di setiap spesimen hasil patahan uji impak. Rongga pada spesimen dapat menurunkan nilai mekanisnya didukung dari hasil uji mekanis.
\end{abstract}

Kata kunci: polypropylene, daur ulang, injection molding, kekuatan tarik, kekuatan impak, fraktografi

\begin{abstract}
The purpose of this study was to see how the differences in injection temperature affect the mechanical and fractographic properties of recycled polypropylene materials. This research was conducted by making the same multipurpose specimen with ISO 294-1: 2012 with 2 times recycled polypropylene material and fabricating an injection molding machine with a clamping capacity of 70 tons with 2 times recycled polypropylene material. The test was carried out using a tensile test with ISO 527-1 and an impact test using the Charpy ISO 179 method. The fracture impact test was analyzed using a digital optical microscope to determine the fracture fracture of the specimen. The results of digital optical microscope observations show that the fractography of recycled PP specimens with the variation of injection temperature $190^{\circ} \mathrm{C}, 220^{\circ} \mathrm{C}$, and $250^{\circ} \mathrm{C}$ is not too different, there is a cavity in each specimen resulting from the impact test fracture. The cavity in the specimen can decrease its mechanical value, supported by the results of mechanical tests.
\end{abstract}

Keywords: polypropylene, recycling, injection molding, tensile strength, impact strength, fractography

\section{Pendahuluan}

Semakin meningkatnya penggunaan plastik dapat menimbulkan dampak negatif seperti pencemaran lingkungan dan sampah plastik membutuhkan waktu yang panjang 
untuk bisa hancur dan terurai. Pemakaian produk berbahan plastik mempunyai dampak yang buruk terhadap lingkungan. Sahwan dkk [1] melakukan penelitian tentang permasalahan daur ulang limbah sampah plastik. Hasil penelitian menyebutkan bahwa persentase penggunaan limbah sampah plastik relatif meningkat yaitu pada tahun 1981 sebesar 3,67\% sampai tahun 2002 sebesar $8,88 \%$. Hasil ini terus meningkat sehingga diperlukan penanganan yang serius dalam menghadapi limbah sampah plastik.

Bernadeth dan Ariande [2] melakukan penelitian tentang perbandingan sifat mekanik polypropylene murni dengan daur ulang. Penelitian ini menggunakan polypropylene murni dan polypropylene komersial yang biasa digunakan sebagai gantungan baju. Hasil perbandingan kekuatan tarik dan uji kekerasan pada plastik polypropylene murni dan daur ulang tidak ada perubahan yang signifikan. Hasil dari kekuatan tarik $P P$ daur ulang itu lebih rendah dari $P P$ murni yang berkisar $22,1 \%$, pada modulus young juga rendah $8,1 \%$ dan berkurang drastis pada strain-at break sebesar 65,7\%. Dari hasil tersebut PP daur ulang masih mempunyai sifat mekanik yang sama dengan $P P$ murni, di mana $P P$ daur ulang masih layak digunakan untuk aplikasi non-struktural lainnya.

Tiwan [3] melakukan penelitian dengan $P P$ murni dan $P P$ daur ulang. Hasil uji tarik dan uji kekerasan menunjukkan terdapat perubahan antara $P P$ murni dengan $P P$ daur ulang. Hasil uji tarik $P P$ daur ulang menunjukkan bahwa kuat tariknya lebih rendah $22,1 \%$ daripada $P P$ murni. Pengujian kekerasan dilakukan dengan scanning electron microscope (SEM) memperlihatkan $P P$ daur ulang memiliki permukaan lebih datar dengan ukuran butiran lebih kecil dibandingkan dengan permukaan $P P$ murni, yang menunjukkan bahwa bahan $P P$ daur ulang lebih brittle (getas) dibandingkan $P P$ murni. Dapat disimpulkan bahwa $P P$ daur ulang memiliki sifat mekanis yang tidak berubah terlalu signifikan dengan $P P$ murni, sehingga layak digunakan sebagai gantungan pakaian.

Sugeri [4] melakukan penelitian mengunakan mesin injection molding dengan dengan suhu injeksi $200^{\circ} \mathrm{C}$ untuk mengetahui sifat mekanis dari material polypropylene daur ulang 1 kali dan 2 kali. Hasil analisis dari pengujian kuat tarik menunjukkan bahwa polypropylene yang berbahan murnilah yang mempunyai nilai kuat tarik tertinggi dengan nilai $36,228 \mathrm{MPa}$ dan nilai uji impak maksimal pada variasi polypropylene murni sebesar 30,58 Joule. Dari penelitian yang dilakukan dapat diambil kesimpulan bahwa material polypropylene murni dan daur ulang sebanyak dua kali mengalami penurunan yang tidak terlalu jauh maka bahan daur ulang polypropylene $80 \%$ masih layak digunakan kembali.

Untuk mengatasi permasalahan limbah plastik dilakukan pemanfaatan produk menjadi bahan baku kembali. Shent dkk, [5] menyebutkan bahwa dalam daur ulang plastik, dibutuhkan pemisahan plastik menjadi plastik individual sesuai jenis resinnya, yang bertujuan untuk menghasilkan plastik dari bahan daur ulang yang berkualitas. Dalam hal ini contohnya daur ulang plastik dari bahan polypropylene yang mempunyai sifat padat, kuat dan keras sehingga menjadi penyebab penyebaran lingkungan.

Dari penelitian terdahulu bisa disimpulkan bahwa penelitian tentang sifat mekanis dan struktur mikro terhadap bahan polypropylene $(P P)$ sebagai pembuatan produk sudah banyak dilakukan, namun penelitian tentang beda temperatur injeksi bahan polypropylene daur ulang masih belum banyak dilakukan. Maka dari itu dilakukan penelitian dengan beda variasi temperatur injeksi bahan $P P$ daur ulang dengan pengujian mekanis dan struktur mikro dengan tujuan hasil dari pengujian dapat digunakan sebagai referensi. Oleh karena itu, pada penelitian ini dilakukan proses injection molding dengan variasi temperatur injeksi dengan bahan plastik polyprophylene $(P P)$ daur ulang 2 kali, untuk mengetahui pengaruh temperatur injeksi terhadap sifat mekanis dan fraktografi. Dengan referensi dari penelitian sebelumnya peneliti melakukan penelitian dengan variasi temperatur injeksi $190^{\circ} \mathrm{C}, 220^{\circ} \mathrm{C}$, dan $250^{\circ} \mathrm{C}$ bahan $P P$ daur ulang.

\section{Material dan Metode Penelitian}

\subsection{Material}

Material yang digunakan dalam penelitian ini adalah Polypropylene homopolimer (PP) $\mathrm{HI} 10 \mathrm{HO}$ buatan PT Chandra Asri Petrochemical, Indonesia. Polypropylene memiliki beberapa keunggulan diantaranya yaitu, mudah dalam pengolahannya, tahan terhadap 
penyerapan air dan ketahanan kimia yang baik sebagai pelarut. Namun untuk pengaplikasian dibidang rekayasa termoplastik masih terbatas penggunaannya karena memiliki tingkat susut yang tinggi dan temperatur polypropylene yang rendah [6]. Aplikasi polypropylene $\mathrm{HI} 10 \mathrm{HO}$ dalam bidang manufaktur misalnya: material polypropylene diaplikasikan dalam berbagai bidang seperti wadah minuman botol, alat rumah tangga, interior mobil, kotak makan, komponen otomotif. Sifat polypropylene ditunjukkan pada Tabel 2.1.

Tabel 2.1. Sifat polypropylene

\begin{tabular}{lcc}
\hline \multicolumn{1}{c}{ Sifat fisis } & Nilai & Satuan \\
\hline Melt flow rate & 10 & $\mathrm{~g} / 10 \mathrm{menit}$ \\
Massa jenis & 0.9 & $\mathrm{~g} \cdot \mathrm{cm}^{3}$ \\
Tensile yield strength & 35 & $\mathrm{Mpa}$ \\
Tensile yield elongation & 13 & $\%$ \\
Flexural modulus & 1500 & $\mathrm{Mpa}$ \\
Notched Izod impact strength & 30 & $\mathrm{~J} / \mathrm{m}$ \\
Kekerasan Rockwell & 90 & $\mathrm{R}-\mathrm{scale}$ \\
Titik lebur & 163 & ${ }^{\circ} \mathrm{C}$ \\
\hline
\end{tabular}

Sumber: Chandra Asri

\section{$2.2 \quad$ Injection Molding}

Mesin injection molding Meiki $70 \mathrm{~B}$ dengan kapasitas clamping 70 ton digunakan untuk pembuatan spesimen. Spesifikasi mesin dapat ditunjukkan pada Tabel 2.2.

Tabel 2.2. Spesifikasi mesin injeksi

\begin{tabular}{clcc}
\hline \multicolumn{2}{c}{ Nama Bagian dan Spesifikasi } & Satuan & Ukuran \\
\hline \multirow{4}{*}{ Unit injeksi } & Screw & $\mathrm{mm}$ & 32 \\
& Tekanan injeksi & $\mathrm{Kg} / \mathrm{cm}^{2}$ & 2020 \\
& Volume injeksi & $\mathrm{Cm}^{3}$ & 116 \\
& Kecepatan injeksi & $\mathrm{mm} / \mathrm{detik}$ & 136 \\
\hline \multirow{5}{*}{ Unit Pencekaman } & $\mathrm{kN}$ & 687 \\
& Gaya pencekaman & $\mathrm{mm}$ & 630 \\
& Open daylight & $\mathrm{mm}$ & 460 \\
& Mold open stroke & $\mathrm{mm}$ & 170 \\
& Mold height & $\mathrm{mm}$ & $560 \times 560$ \\
& Platen size $(\mathrm{H} \times \mathrm{V})$ & $\mathrm{mm}$ & $3850 \times 1100 \times 1600$ \\
\hline
\end{tabular}

\subsection{Tahapan Penelitian}

\subsubsection{Persiapan Bahan Baku}

Pada tahapan ini bahan baku yang digunakan adalah polypropylene (PP) $\mathrm{HI} 10 \mathrm{HO}$ murni yang diproduksi dengan temperatur $200^{\circ} \mathrm{C}$ dan didaur ulang sebanyak 2 kali menggunakan mesin crusher. Membuat spesimen dengan 3 variasi temperatur injeksi yaitu dengan temperatur $190^{\circ} \mathrm{C}, 220^{\circ} \mathrm{C}$, dan $250^{\circ} \mathrm{C}$.

\subsubsection{Persiapan Bahan Baku}

Pembuatan spesimen dalam kondisi optimal tidak lepas dari parameter yang sesuai dalam pembuatan spesimen material polypropylene untuk mengurangi terjadinya cacat yang terjadi pada spesimen [7]. Pembuatan spesimen multipurpose standar ISO 294 menggunakan mesin injection molding dengan kapasitas 70 ton menggunakan material polymer polypropylene $\mathrm{HI} 10 \mathrm{HO}$ daur ulang. Langkah - langkah dalam pembuatan spesimen adalah sebagai berikut:

a) Persiapan material $P P$ murni sebanyak $10 \mathrm{~kg}$. 
b) Mengatur parameter temperatur material pada tiap pemanas (Gambar 2.1), tekanan saat injeksi, dan tekanan holding agar material $P P$ melebur dan menginjeksi dengan optimal. Parameter temperatur PP ditunjukan pada Tabel 2.3, Tabel 2.4, dan Tabel 2.5.

c) Proses produksi sebanyak 45 buah ( 15 buah variasi temperatur $190^{\circ} \mathrm{C}, 15$ buah daur variasi temperatur $220^{\circ} \mathrm{C}$, dan 15 buah variasi temperatur $\left.250^{\circ} \mathrm{C}\right)$.

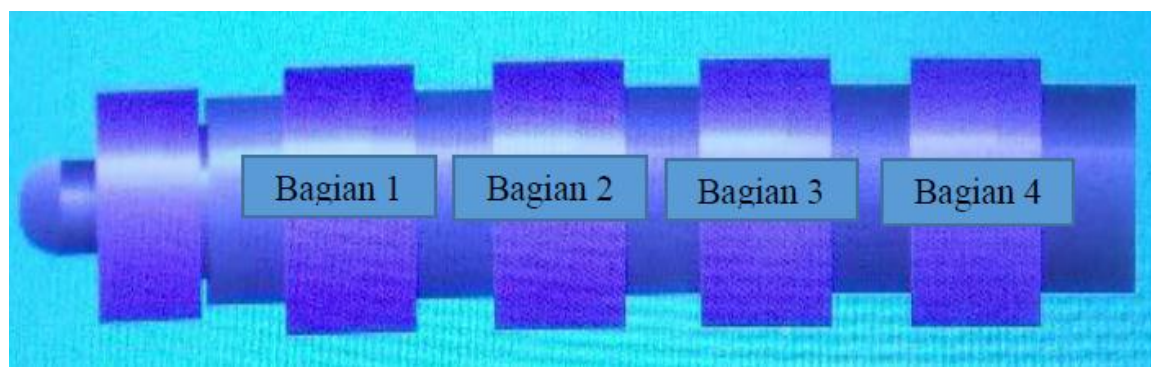

Gambar 2.1. Bagian pemanas barel injeksi

Tabel 2.3. Parameter tekanan injeksi

\begin{tabular}{ccccc}
\hline \multirow{2}{*}{$\begin{array}{c}\text { Suhu Nozzle } \\
\left({ }^{\circ} \mathbf{C}\right)\end{array}$} & Bagian 1 & Bagian 2 & Bagian 3 & Bagian 4 \\
\cline { 2 - 5 } & 130 & 127 & 120 & 117 \\
\hline 190 & 125 & 122 & 120 & 117 \\
220 & 130 & 125 & 122 & 117 \\
250 & & &
\end{tabular}

Tabel 2.4. Parameter holding

\begin{tabular}{ccccc}
\hline & & & \\
Parameter & Bagian 1 & Bagian 2 & Bagian 3 & Bagian 4 \\
\cline { 2 - 5 } & & 80 & 80 & 80 \\
\hline Tekanan (bar) & 80 & 3 & 3 & 3 \\
Waktu (detik) & 3 & & & \\
\hline
\end{tabular}

Tabel 2.5. Parameter Temperatur material plastik PP Daur Ulang

\begin{tabular}{ccccc}
\hline \multicolumn{5}{c}{ Setting Temperatur $\left({ }^{\circ} \mathbf{C}\right)$} \\
Suhu Nozzle & Bagian 1 & Bagian 2 & Bagian 3 & Bagian 4 \\
\hline 190 & 190 & 180 & 170 & 160 \\
220 & 220 & 200 & 190 & 180 \\
250 & 250 & 235 & 200 & 190 \\
\hline
\end{tabular}

\subsubsection{Pengukuran Spesimen}

Pada tahapan ini melakukan pengukuran pada spesimen yang telah diproduksi untuk mendapatkan nilai rata - rata lebar dan rata-rata ketebalan.

\subsubsection{Pengujian Produk}

Pengujian yang dilakukan meliputi uji tarik mengikuti standar ISO 527 dan uji impak sesuai standar ISO 179 [8]. 


\section{Hasil dan Pembahasan}

\subsection{Hasil Spesimen Multipurpose}

Hasil spesimen $P P$ daur ulang dengan temperatur injeksi $190^{\circ} \mathrm{C}, 220^{\circ} \mathrm{C}$, dan $250^{\circ} \mathrm{C}$ ditunjukkan pada Gambar 3.1.

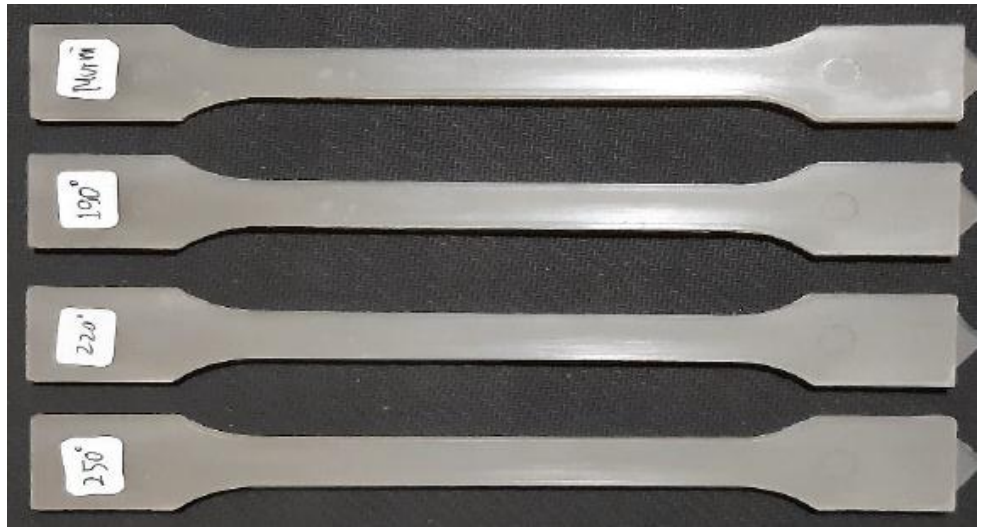

Gambar3.1Spesimen multipurpose polypropylene daur ulang

\subsection{Hasil Pengukuran Spesimen}

Gambar 3.2 menjelaskan bahwa dimensi pada spesimen telah sesuai dengan standar 527-1 dapat ditetapkan toleransi untuk dimensi specimen multipurpose tersebut adalah nilai tebal $4 \mathrm{~mm} \pm 0,5$ dan lebar $10 \mathrm{~mm} \pm 0,5$. Pengukuran lebar dari spesimen $P P$ daur ulang menggunakan alat jangka sorong, didapatkan nilai rata-rata ketebalan minimum yaitu 3,98 $\mathrm{mm}$ dan nilai ketebalan maksimum 4,04 mm. Untuk nilai rata-rata lebar minimum diperoleh $9,87 \mathrm{~mm}$ dan nilai rata-rata lebar maksimum sebesar $9,89 \mathrm{~mm}$.

Syarat lain untuk melakukan pengujian selain dimensi ukuran adalah bentuk spesimen yang tidak memiliki cacat, karena bentuk spesimen yang memiliki cacat akan menghasilkan nilai kekuatan uji yang tidak seragam. Jenis cacat yang dapat memengaruhi nilai pada saat pengujian adalah cacat bubbles (gelembung udara). Penyebab cacat bubbles adalah udara yang masih terperangkap didalam silinder injeksi atau udara yang masih terjebak didalam cavity.

\section{Rata-rata Tebal dan Lebar}

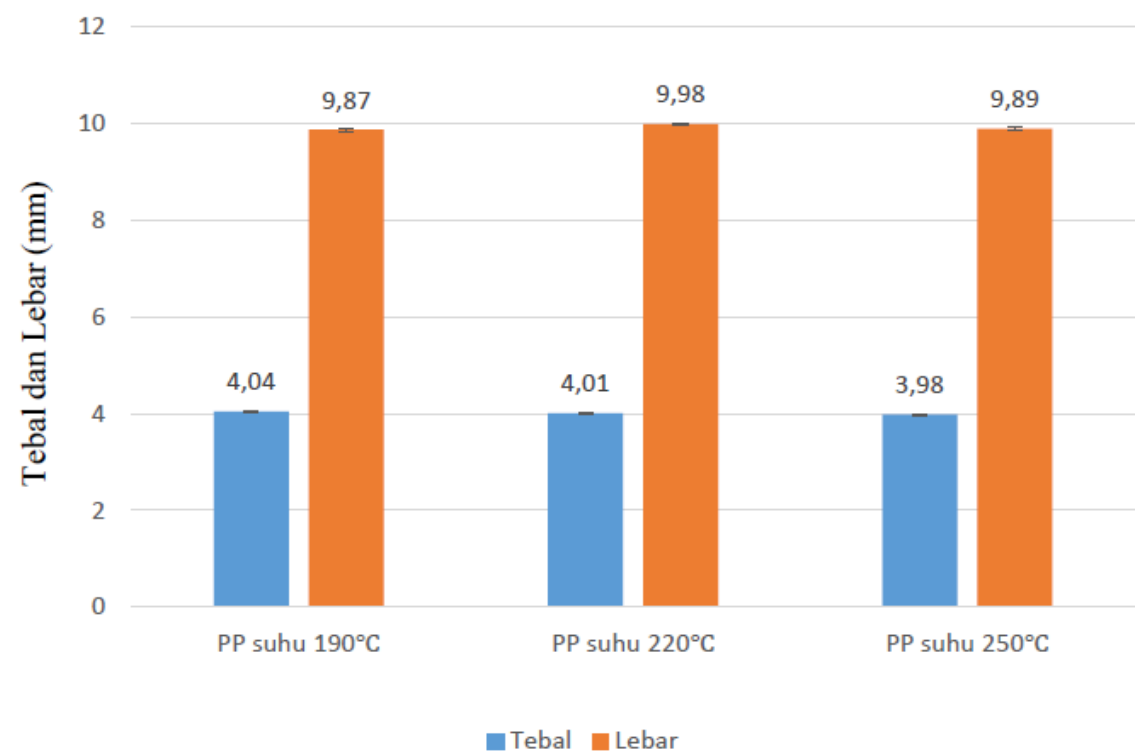

Gambar 3.2. Grafik nilai rata-rata tebal dan lebar spesimen 


\subsection{Hasil Pengujian Tarik}

Gambar 3.3 menjelaskan bahwa, pada variasi temperatur $190^{\circ} \mathrm{C}$ nilai rata-rata uji tarik dari 5 spesimen yaitu sebesar $33,2 \mathrm{MPa}$. Dari 5 spesimen uji tarik didapatkan nilai maksimum pada spesimen yang ke-1 yaitu sebesar $33,7 \mathrm{MPa}$ dan nilai minimum pada spesimen ke-4 yaitu sebesar 32,8 MPa.

Pada variasi temperatur $220^{\circ} \mathrm{C}$ nilai rata-rata uji tarik dari 5 spesimen yaitu sebesar 32,4 $\mathrm{MPa}$. Dari 5 spesimen uji tarik didapatkan nilai maksimum yang sama yaitu pada spesimen yang ke-3 dan ke- 5 yaitu sebesar $32,8 \mathrm{MPa}$ dan nilai minimum pada spesimen ke1 yaitu sebesar $32,4 \mathrm{MPa}$.

Pada variasi temperatur $250^{\circ} \mathrm{C}$ nilai rata-rata uji tarik dari 5 spesimen yaitu sebesar 33,1 $\mathrm{MPa}$. Dari 5 spesimen uji tarik didapatkan nilai maksimum yang sama yaitu pada spesimen yang ke-1,2, dan 4 yaitu sebesar $33,2 \mathrm{MPa}$ dan nilai minimum pada spesimen ke3 yaitu sebesar $32,9 \mathrm{MPa}$.

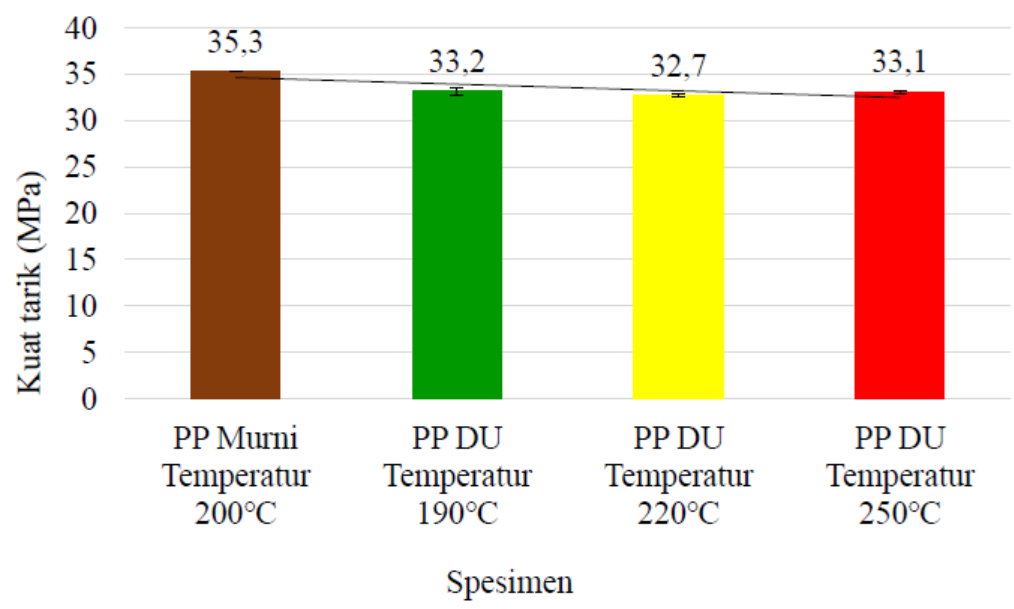

Gambar 3.3. Nilai rata-rata tegangan

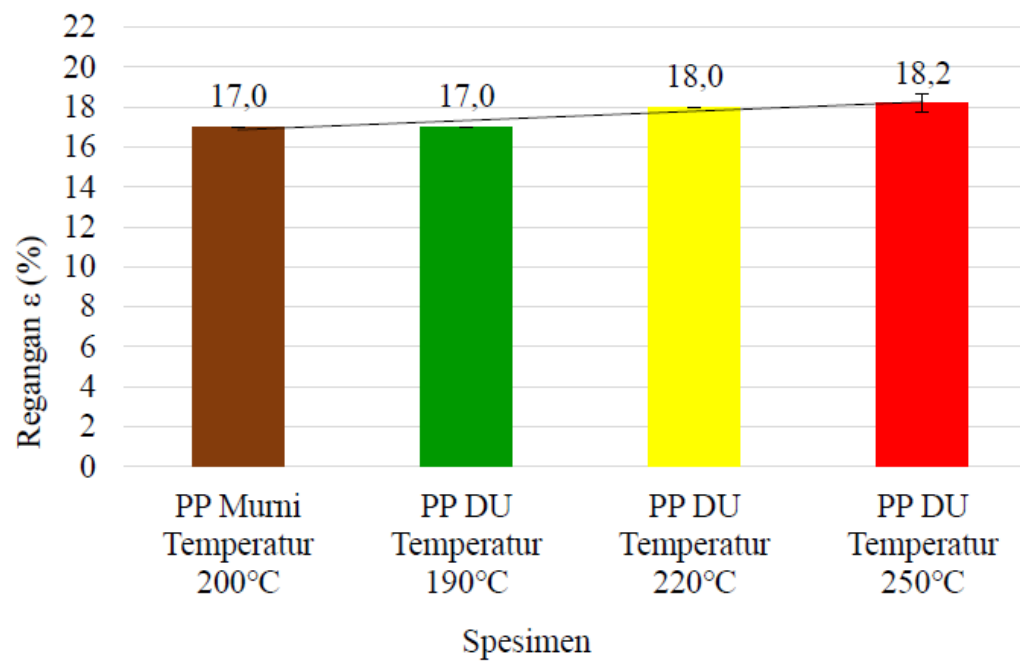

Gambar 3.4. Nilai rata-rata regangan 


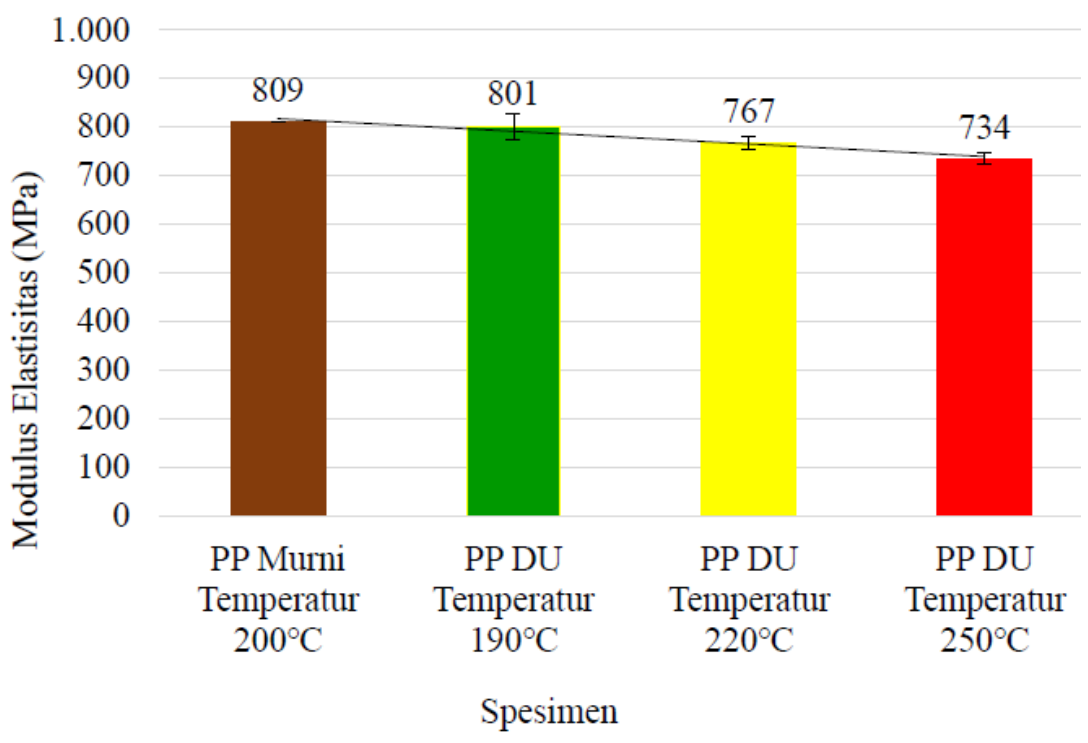

Gambar 3.5. Nilai rata-rata modulus elastisitas

Pada Gambar 3.3. dijelaskan dari hasil data pengujian variasi temperatur injeksi material $P P$ daur ulang 2 kali, diketahui bahwa penurunan nilai tegangan dari material $P P$ daur ulang 2 kali tidak mengalami terlalu banyak perubahan pada nilai tegangannya. Jika dibandingkan dengan $P P$ murni nilai tegangan sebesar 35,3 MPa, penurunan nilai tegangan terjadi pada tiap variasi temperatur injeksi. Penurunan nilai tegangan terbesar terjadi pada variasi temperatur $220^{\circ} \mathrm{C}$, nilai rata-rata dari 5 spesimen pengujian yaitu sebesar $32,7 \mathrm{MPa}$ terendah dari nilai tegangan variasi $190^{\circ} \mathrm{C}$ dan $250^{\circ} \mathrm{C}$. Hal ini dikarenakan semakin tinggi temperatur pada proses injeksi maka semakin rendah nilai ketahan sifat mekanis pada material daur ulang. Menurut Bernadeth [2] PP daur ulang masih mempunyai sifat mekanik yang sama dengan $P P$ murni sehingga masih layak digunakan untuk aplikasi non-struktural lainnya.

Pada Gambar 3.4 dijelaskan dari pengujian variasi temperatur injeksi material $P P$ daur ulang 2 kali, diperoleh fakta bahwa semakin rendah nilai regangan dapat mengakibatkan spesimen daur ulang tersebut menjadi getas. Jika dibandingkan dengan $P P$ murni dengan nilai regangan sebesar $17 \%$, dapat dilihat terjadinya kenaikan nilai regangan pada $P P$ DU variasi temperatur $220^{\circ} \mathrm{C}$ dan $250^{\circ} \mathrm{C}$. Nilai perubahan regangan tertinggi didapat pada variasi temperatur $250^{\circ} \mathrm{C}$ yaitu sebesar $18,2 \%$ mengalami kenaikan yang cukup signifikan. Menurut Asror (2003) perubahan temperatur dan tekanan injeksi pada proses injection molding terhadap material plastik daur ulang berpengaruh signifikan pada hasil regangan produk tersebut. Hal itu terjadi karena proses pemanasan dan tekanan pada saat injeksi kemudian pengaruh banyaknya kadar amorf pada material dapat meningkatkan kekerasan.

Pada Gambar 3.5 dijelaskan bahwa pada material PP DU terjadi penurunan nilai modulus elastisitas yang cukup signifikan, hasil uji PP DU dengan modulus elastisitas tertinggi terjadi pada variasi temperatur $190^{\circ} \mathrm{C}$, nilai rata-rata modulus elastisitas yaitu sebesar $801 \mathrm{MPa}$ dan nilai rata-ratamodulus elastisitas terendah yaitu pada variasi temperatur $250^{\circ} \mathrm{C}$ yaitu sebesar $734 \mathrm{MPa}$. Dapat dilihat dari data pengujian bahwa penurunan nilai modulus elestisitas dipengaruhi oleh bahan daur ulang dan temperatur injeksi, hal ini dikarenakan semakin tinggi temperatur injeksi $P P$ daur ulang pada saat pembuatan produk maka nilai modulus elastisitasnya semakin menurun.

\subsection{Hasil Pengujian Impak}

Hasil dari data pengujian impak polypropylene daur ulang 2 kali pada temperatur injeksi $190^{\circ} \mathrm{Cdidapatkan}$ nilai rata-rata energi impak sebesar $3,01 \mathrm{KJ} / \mathrm{m}^{2}$, pada temperatur injeksi $220^{\circ}$ Cdidapatkan nilai rata-rata energi impak sebesar $2,27 \mathrm{KJ} / \mathrm{m}^{2}$ dan pada temperatur injeksi $250^{\circ} \mathrm{Cdiperoleh} \mathrm{nilai} \mathrm{rata-rata} \mathrm{energi} \mathrm{impak} \mathrm{sebesar} 1,77 \mathrm{KJ} / \mathrm{m}^{2}$. Nilai kuat impak $P P$ sebesar $4,5 \mathrm{KJ} / \mathrm{m}^{2}$, lebih tinggi dari hasil pengujian impak $P P$ daur ulang pada semua variasi temperatur. Dapat diketahui bahwa hasil dari pengujian material polypropylene 
daur ulang variasi temperatur memiliki nilai penurunan yang signifikan terhadap temperatur injeksi.

Dari Gambar 3.6 dapat diketahui bahwa semakin tinggi nilai kekuatan impak yang di hasilkan pada spesimen PP daur ulang maka semakin baik dalam ketahanan menerima beban kejut yang datang dan semakin lunak. Bentuk type of failure patahan dari spesimen $P P$ daur ulang tersebut dikategorikan tipe C (completebreak), artinya patahan yang dihasilkan adalah sempurna ketika diberi energi dari pendulum sebesar 0,5 Joule yang disesuaikan denggan standar ISO 179-1 material polypropylene, sehingga plastik tersebut cenderung getas (Gambar 3.7).

Tekanan pada saat melakukan proses injeksi memengaruhi kekuatan energi impak menjadi turun. Menurut Asror [8]pengaruh suhu proses dan tekanan injeksi berpengaruh terhadap nilai kekuatan energi impak dengan standar ISO 179-1 pada proses pembuatan spesimen. Semakin tinggi suhu dan tekanan injeksi pada saat proses produksi, maka semakin meningkatkan atom-atom yang tersusun secara tidak teratur (amorphous) yang terbentuk pada material plastik tersebut.

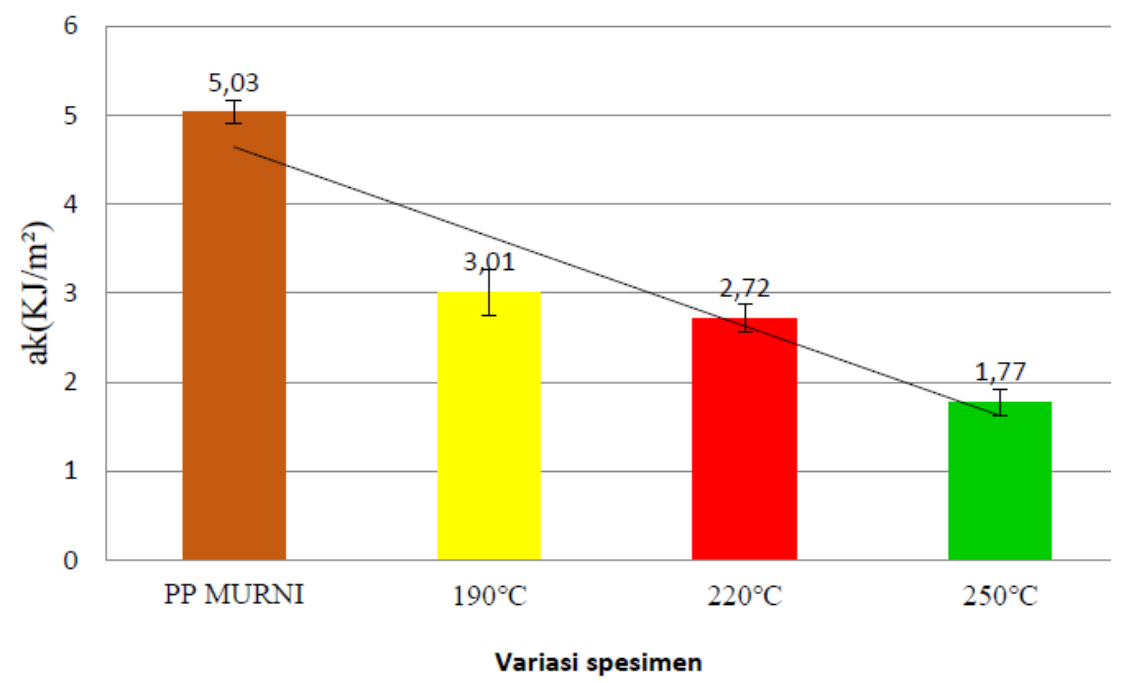

Gambar 3.6. Nilai rata-rata kuat impak

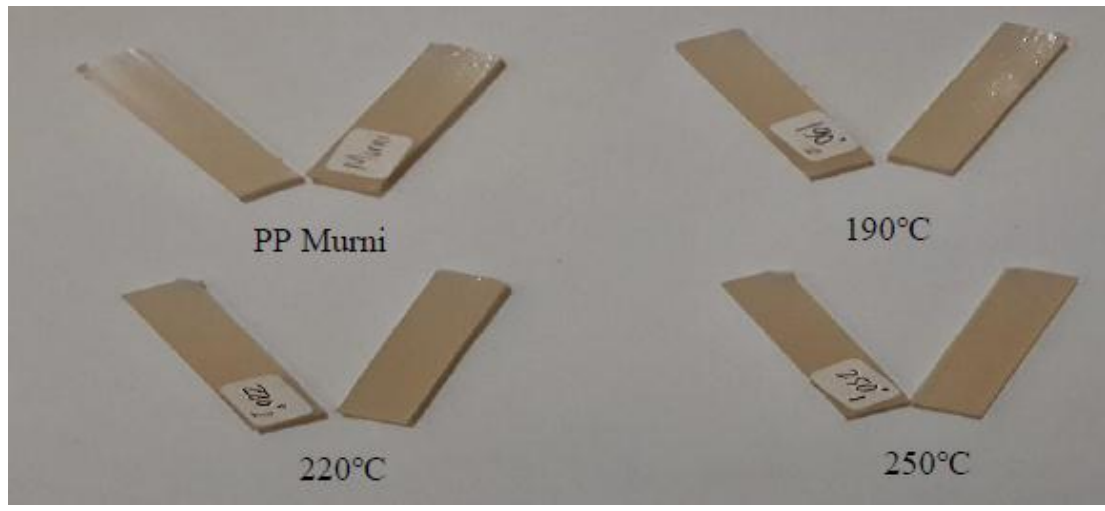

Gambar 3.7. Kondisi patah complete break pada semua spesimen

Penurunan kuat impak pada kondisi suhu injeksi yang semakin tinggi berkaitan dengan tingkat void pada penampang spesimen [9] seperti ditunjukkan pada Gambar 3.8. Pada gambar tersebut ditunjukkan fraktografi untuk $P P$ DU hasil injeksi dengan suhu $190^{\circ} \mathrm{C}$, $220^{\circ} \mathrm{Cdan} 250^{\circ} \mathrm{C}$ menggunakan mikroskop optik digital pada patahan impak. 

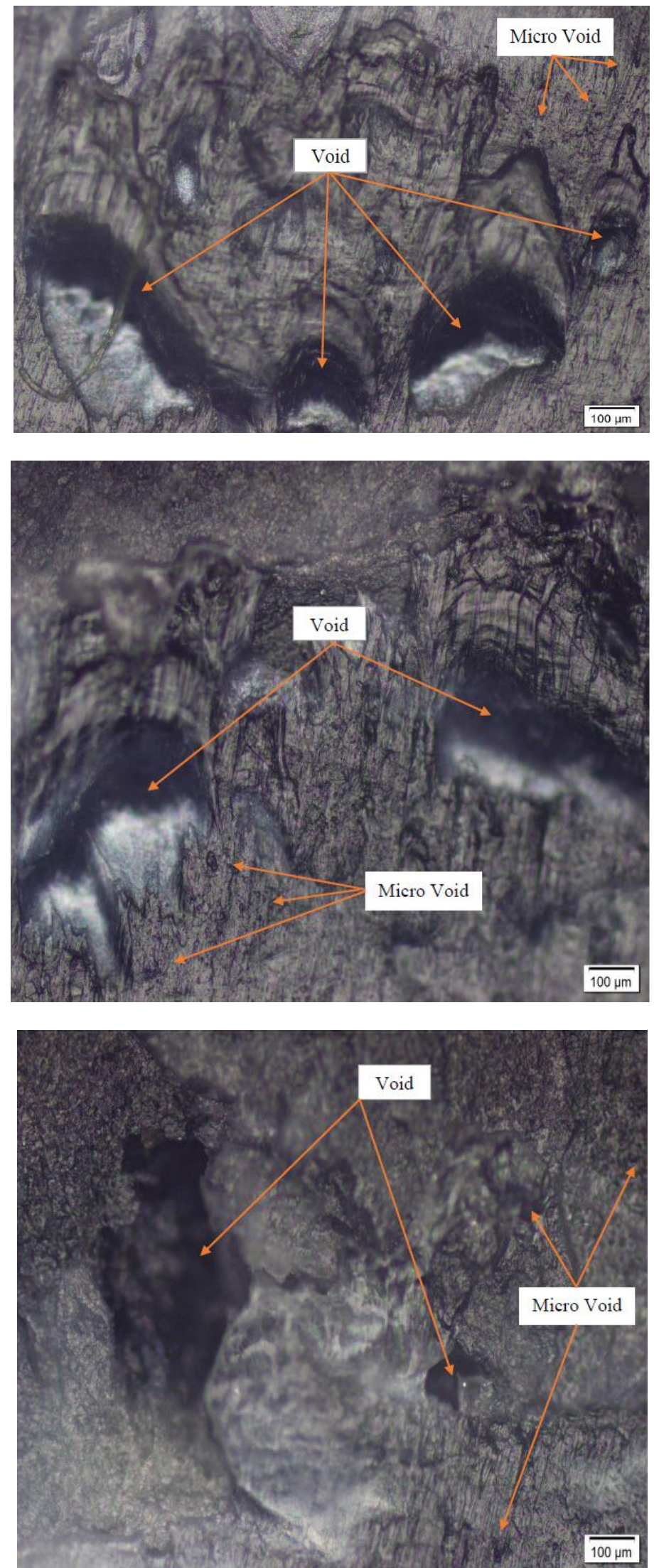

Gambar 3.8. Fraktografi pada penampang patah uji impak: (a) Suhu $190{ }^{\circ} \mathrm{C}$; (b) suhu $220{ }^{\circ} \mathrm{C}$; (c) suhu $250{ }^{\circ} \mathrm{C}$ 
Jika dilihat pada hasil pengujian dapat dijelaskan bahwa pada temperatur injeksi $250^{\circ} \mathrm{C}$ terdapat rongga yang cukup besar dibandikan pada variasi temperatur $190^{\circ} \mathrm{C}$ dan $220^{\circ} \mathrm{C}$. Hal ini menunjukan bahwa $P P$ daur ulang temperatur injeksi $250^{\circ} \mathrm{C}$ memiliki luas penampang yang lebih kecil dari variasi temperatur $190^{\circ} \mathrm{C}$ dan $220^{\circ} \mathrm{C}$ yang akan mengakibatkan penurunan nilai uji mekanisnya. Ada beberapa penyebab void pada spesimen yaitu gas yang masih terperangkap di dalam silinder dan udara yang masih terjebak di dalam cavity.

Menurut Grogore[10] semakin tinggi suhu dan tekanan injeksi pada saat proses produksi, maka semakin meningkatkan atom-atom yang tersusun secara tidak teratur (amorphous) yang terbentuk pada material plastik tersebut.

\section{KesimpULAN}

Berdasarkan hasil dari penelitian tentang pengaruh beda temperatur proses injeksi terhadap sifat mekanis bahan Polypropylene (PP) daur ulang, maka dapat disimpulkan sebagai berikut:

a) Hasil analisa dari pengujian kuat tarik secara keseluruhan menunjukkan bahwa material polypropylene daur ulang dengan variasi temperatur antara $190^{\circ} \mathrm{C}, 220^{\circ} \mathrm{C}$ dan $250^{\circ} \mathrm{C}$ dengan tekanan injenksi yang sama tidak mengalami penurunan nilai yang signifikan. Hal ini dibuktikan dengan nilai kekuatan tarik terbesar yaitu sebesar 33,2 MPa pada variasi temperatur $190^{\circ} \mathrm{C}$ sedangkan pada material PP murni temperatur $200^{\circ} \mathrm{C}$ sebesar 35,3 $\mathrm{MPa}$ (penurunan sebesar 5,95\%). pada nilai uji impak pada $P P$ murni temperatur injeksi $200^{\circ} \mathrm{C}$ nilai iji impaknya sebesar $5,03 \mathrm{KJ} / \mathrm{m}^{2}$. Pada $P P$ daur ulang variasi temperatur injeksi $190^{\circ} \mathrm{C}$ sebesar $3,01 \mathrm{KJ} / \mathrm{m}^{2}$ (penurunan sebesar 40,12\%) dan yang terendah $P P$ daur ulang variasi temperatur injeksi $250^{\circ} \mathrm{C}$ sebesar $1,77 \mathrm{KJ} / \mathrm{m}^{2}$ (penurunan sebesar $64,81 \%$ ). Penggunaan bahan daur ulang sebagai produk polypropylene dapat menurunkan sifat mekaniknya, diantaranya uji tarik dan uji impak, karena bahan yang digunakan sudah melalui proses pembentukan dan proses pemanasan berulang-ulang.

b) Hasil dari fraktografi menunjukkan bahwa temperatur injeksi berpengaruh terhadap rongga (void) pada spesimen hasil produksi. Hasil dari patahan impak menggunakan mikroskop optik digital memperlihatkan bahwa besar dan banyaknya jumlah void akan mengurangi luas penampang spesimen yang mengakbatkan berkurangnya kekuatan material tersebut. semakin besar rongga (void) yang terdapat pada spesimen maka akan mengurangi nilai kuat impaknya, yang akan mengakibatkan spesimen lebih getas.

\section{REFERENSI}

[1] Sahwan, Firman L. Sistem Pengelolaan Limbah Plastik di Indonesia. Jurnal Penelitian. 2005; 6 (1): 311-318.

[2] Bernadeth, J.H.J.Studi perbandingan sifat mekanik polypropylene murni dan daur ulang. Thesis. Depok: Program Pascasarjana Fisika, Departemen fisika, Fakultas Matematika dan Ilmu Pengetahuan Alam, Universitas Indonesia; 2010.

[3] Tiwan. Pengaruh penambahan bahan daur ulang pada kekuatan tarik, modulus elastisitas dan kekerasan bahan acrylonitrile butadiene styrene (ABS). UNY Yogyakarta. 2008; 1-8.

[4] Sugeri, A. Komparasi sifat mekanis polipropilen dari bahan polipropilen murni dengan variasi baur ulang 1 kali dan 2 kali. Thesis. Yogyakarta: Program Study Teknik Mesin, Fakultas Teknik, Universitas Muhammadiyah Yogyakarta. 2018. 
[5] Shent, H., Pugh R.J., and Forssberg, E. A Review of Plastics Waste Recycling and the Flotation of Plastics. Journal of Resources, Conservation and Recycling. 1999; 25 (2): 85-109.

[6] DeBoest, J.F., Dostal C.A. and Reinhart J.1988,Reinforced polypropylenes, Engineering plastics. ASM International, 192-193.

[7] Mawardi, I., Hasrin dan Hanif. Analisis Kualitas Produk dengan Pengaturan Parameter Temperatur Injeksi Material Plastik Polypropylene (PP) Pada Proses Injection Molding. Malikussaleh Industrial Engineering Journal. 2015; 4 (2) 30-35.

[8] Asror, M.F., dan Torno, H.S.S., 2003. Pengaruh suhu proses dan tekanan injection moulding terhadap kekuatan benturan dan kekerasan pada material High density polyethylene. Prosiding symposium nasional polimer IV Sentra Teknologi Polimer (STP)BPPT, 188-192.

[9] Naik L. A Study on Reducing the Sink mark in Plastic Injection Moulding - Taguchi Technique. International Journal of Engineering Research and Development.2014; 10 (3) $40-43$.

[10] Grogore, M.E. Methods of recycling, properties, and applications of recycled thermoplastic polymers. Thesis. Bucharest: Department of Polymers, National Research \& Development Institute for Chemistry \& Petrochemistry (ICECHIM), Faculty of Engineering in Foreign Languages, University Politehnica of Bucharest, Romania. 2017 